\title{
STRATEGIC MANAGEMENT OF SALES PROMOTION TECHNIQUES ON PRODUCTS CONSUMERS OF SELECTED RETAIL OUTLETS IN CALABAR METROPOLIS OF CROSS RIVER STATE, NIGERIA
}

\author{
CHARLES EFFIONG, EFFIOM EFFIOM INAMETI, NAOMI A. ERNEST AND \\ NNEOYI NNANA ARIKPO
}

(Received 23 May 2018; Revision Accepted 4 July 2018)

\begin{abstract}
The rapid change in global market and competition elevation, has increasingly made sales promotion strategies contemporary inevitable for market success. The study examines the strategic management of sales promotion techniques on products consumers of selected retail outlets in Calabar Metropolis, Cross River State, Nigeria. The study adopted the survey research design while a two stage sampling design: the stratified random and judgmental sampling were used in the sample selection. The one way ANOVA and multiple regression analysis were adopted for data estimation. The study established that there is significant effect of free sample on products consumers in selected retail outlets in Calabar Metropolis. The study recommended that Retailers should endeavor to engage in sales promotions strategies vigorously as this would promote sales volume in order to obviate expiry date of some products on the shelf. Also, giving free products to consumers and charging a token should be discouraged, as this practice disenchant many consumers and impairs brand loyalty as many consumer are not ready to come back to patronize such product.
\end{abstract}

KEYWORDS: Strategic management, Sales promotion, Consumers, Retail outlets, Cross River State

\section{INTRODUCTION}

Success in business indeed is no longer a chance factor but on a meticulously articulated planning by strategically crafting a competitive advantage above others in the market place (Effiong \& Ekpenyong, 2010). Contemporary, the complex and dynamic business environment which features uncertainty and risk, high rate of business competition, and consumers' discretional purchasing power, inevitably requires that business organization must calve a niche in the market space to building brand loyalty through effectively and efficiently satisfying their needs. It is on this premises of delivering the desired satisfaction than its competitors that promotional strategies evolve (Effiong \& Ekpenyong, 2010).

Globally, the fundamental hallmarks of market competition is changing and the pace of these changes is relentless and increasing (Hitt, Hoskisson, Harrison, \& Summers, 1994). Thus, Bettis and Hitt, (1995) posited that competitions and strategies in the late 21 st century is moving toward a 'new competitive landscape' which epitomizes new issues, concepts, problems, and challenges to promote sales and brand loyalty. Sequel, Strategic management of sales promotion techniques on products consumers in retail outlets becomes imperative. Strategic

Charles Effiong, Department of Business Management, University of Calabar, Cross River State, Nigeria.

Effiom Effiom Inameti, Department of Marketing, University of Calabar, Cross River State, Nigeria.

Naomi A. Ernest, Department of Marketing, University of Calabar, Cross River State, Nigeria.

Nneoyi Nnana Arikpo, Department of Business Management, University of Calabar, Cross River State, Nigeria.

(C) 2018 Bachudo Science Co. Ltd. This work is licensed under Creative Commons Attribution 4.0 International license. 
management involves identifying how the firm gears up compared to its competitors, and recognizing opportunities and threats facing a firm, whether they come from within the firm or from competitors. To remain successful, firms need to articulate strategically on sales promotions techniques. Hitt, Ireland, and Hoskisson, (2017:30) buttressed that:

"Strategic management process is intended to be a rational approach to help a firm effectively respond to the challenges of the $21^{\text {st }}$ century competitive landscape. The process requires a firm to study its external and internal environment and to identify market place opportunities and threats and determine how to use its core competencies in the pursuit of desired strategic outcome. With this knowledge, the firm forms a strategy intent to leverage its resources, capabilities, and core competencies to win competitive battles".

It is against this background that this study examines the strategic management of sales promotion techniques on products consumers in retail outlets in Calabar Metropolis in Cross River State.

"Sales promotion is a key ingredient in marketing campaigns, consists of a collection of incentive tools, mostly short term, designed to stimulate quicker or greater purchase of particular products or services by consumers. Whereas advertising offers a reason to buy, sales promotion offers an incentive to buy. Sales promotion includes tools for consumer promotion thus: samples, coupons, cash refund offers, prices off, premium, prizes, patronage rewards, free trials, warranties, tie-in promotions, crosspromotion, point of purchase displays, and demonstrations" (Kotler, 2002).

Sales promotion tools vary in their specific objectives. A free sample stimulates consumer trial, whereas a free management advisory service aims at cementing a long-term relationship with consumers and other channel members. Sellers use incentives type promotion to attract new triers, to reward loyal customers, and to increase the repurchase rates of occasional users. Sales promotions often attract brand switchers, who are primarily looking for low price, good value, or premiums. If some of them would not have otherwise tried the brand, promotion can yield long-term increases in market share (Koukova, Srivastava \& SteulFischer, 2012).

Sales promotions in marketing of high brand similarity can produce a high sales response in the short run but little permanent gain in brand preference over the longer term. In marketing of high brand dissimilarity, they may be able to alter market shares permanently. In addition to brand switching, consumers may engage in stockpiling-purchasing earlier than usual that is purchase acceleration or purchasing extra quantities. But sales may then hit a postpromotion dip (Kotler \& Armstrong, 2013).

A number of sales promotion benefits flow to manufacturer and consumers. Manufacturers can adjust to short-term variations in supply and demand and test how high a list price they can charge, because they can always discount it. Promotions induce consumers to try new products and lead to more varied retail formats, such as everyday low pricing and promotional pricing. For retailers promotions may increase sales of complementary categories as well as induce store switching. They promote greater consumer awareness of prices. They help manufacturers sell more than normal at the list price and adapt programmes to different consumer segments. Service marketers also employ sales promotions to attract new customers and establish loyalty (Xia, \& Monroe, 2004).

Retailing includes all the activities in selling goods or services directly to final consumers for personal or non-business use. A retailer or retail outlet is any business enterprise whose sales volume comes primarily from retailing. An organization selling to final consumers, whether it is a manufacturer, wholesaler, or retailer, is doing retailing. It doesn't matter how the goods or services are sold (in person, by mail, telephone, vending machine, or on the internet) or where (in a store, on the street or in the consumer's home). Therefore, strategic management of sales promotion techniques of selected retail outlets is paramount and the basis of this study.

\subsection{Statement of the problem.}

In the emerging business scenario various promotional techniques are used by the marketers to influencing the purchase decision of their consumers. Sales promotions, a key 
element of promotional mix has been widely used to sustain competitive advantage, increase sales and stimulate consumer purchase decision, thus becoming a valuable tool for marketers to influence purchase decision. Many retail outlets have missed the opportunities of sales increment due to inability to apply the right sales promotion techniques at appropriate time and season. Strategic management failure of this nature would cause non-purchased products to over stay on counter of retail outlets which may lead to products expiration and eventually result onto decline stage of product life cycle. The effect of this problem is capable of destroying employment opportunities and dwindling income generation in the organization since un-purchased goods may eventually expired, become loss to retail outlet in sales, profit and loss account and balance sheet. This study sought to examine the strategic management of sales promotion techniques on products consumers of selected retail outlets in Calabar metropolis of Cross River State.

\subsection{Objective of the study}

The major objective of this study was to ascertain the effect of sales promotion techniques on products consumers of selected retail outlets in Calabar Metropolis. Specifically, the study sought to:

1. Establish how sales promotions techniques affect customers' motivation to participate in sales promotions campaign.

2. Determine the effect of free sample on products consumers of selected retail outlets in Calabar Metropolis

\section{$1.4 \quad$ Research Questions}

The following research questions were used in this study.

1. How does sales promotions techniques affect consumers' motivation to participate in sales promotion campaign?

2. To what extent does free sample affect products consumers of selected retail outlets in Calabar metropolis?

\subsection{Research Hypotheses}

The research hypotheses for this study

were:

1. Sales promotions techniques does not significantly affect consumers' motivation to participate in sales promotion campaign.
2. There is no significant effect of free sample on products consumers of selected retail outlets in Calabar metropolis.

\subsection{Significance of the study}

The findings of this study shall benefit the following: operators of retail businesses, marketing practitioners and the academia. Operators of retail businesses shall find the recommendations of this study very useful because the study has made it clear the secret concepts of sales promotion to the members of channel of distribution including retailers. Also, marketing practitioners will benefit from the findings of this study on the basis of application of marketing consultancy to marketing organizations within and outside Nigeria. The marketing consultants will be able to give advice concerning sales promotion tactics base on the result of this study. The academic sector will depend on the literature of this study because the study of this nature has added to the bedrock of sales promotion literature.

\subsection{Scope of the study}

This study examined the strategic management of sales promotion techniques on products consumers of selected retail outlets in Calabar metropolis. The selected retail outlets comprises: Spar shopping mall, Pero cosmetic Investment, D Choice bar, UDEC phones plaza and Ibedmore Ltd., jn the Calabar metropolis of Cross River State.

\subsection{Limitations of the study}

The study was constraint by a large number of sample size and there was difficulty in accessing the respondents' attention during shopping. This limitation was overcome by explaining the purpose of the study to the buyers and solicited for their cooperation.

\subsection{REVIEW OF RELATED LITERATURE}

\section{$2.1 \quad$ Theoretical framework}

This study was anchored on Strategic Management Theory (SMT),Theory of Retailer Price Promotions (TRPP) and Rational Choice Theory (RCT).

\subsubsection{Strategic management theory (SMT)}

Strategic management theory connotes a supposition, proposition or a system of ideas proposed to explicate "the origin, evolution, 
principles and applications of strategic management. The strategic management theories mainly stem from the systems perspective, contingency approach and information technology approach to corporate management" (Omalaja \& Eroula, 2011). The common strategic management theories noted and applicable to organizational success are: the profit-maximising and competition-based theory; resource-based theory; survival-based theory; human resource-based theory, agency theory and contingency theory (David \&David, 2015; Hashim, 2005). The profit-maximising and competition-based theory is based on the notion that firm's mission and main objective is to maximize long term profit through developing sustainable competitive advantage over competitive rivals in the external market place. The perspective basis of this theory view the firm's external market positioning as the critical factor for attaining and sustaining competitive advantage over competitive rivals. In another perspective, the resource-based theory stems from the management philosophy that firm's competitive advantage lies in the firm's internal resources, as opposed to their external environment positioning (Effiong, Usoro, \& Ekpenyong, 2017). Thus, Barney, (1995) postulated that competitive advantage strongly depends on the unique, inimitable resources and capabilities the firm possesses, rather than simply evaluating environmental opportunities and threats in conducting business. The survivalbased theory centers on the management philosophy that firms need to continuously adapt to its competitive environment in order to survive and remain in business. The human-based theory emphasizes the importance of human element in the strategy development process of the firm. The Agency theory underlies the important relationship between the shareholders (firm owners) and agents (firm managers) in ensuring the firm successes. Lastly, the contingency theory holds the management tenet that there is no one best approach or method to manage an organization but the management strategy should be based on the situation and condition being experienced.

For the purpose of this study, besides other main strategic management theories as mention above, the profit-maximising and competition-based theory would be the underlying theoretical foundation applied and fundamental basis of the variables.
2.1.2 Theory of Retailer Price Promotions (TRPP) (Slutsky, 1915)

The theory states that under several conditions that completely apply to consumer goods, incremental retail sales generated by promotional price discounts are entirely incremental to the promoting manufacturer, the promoting retailer and the category, overall. In general and as observed, examining traditional retail point-of- sale data, implies that there is no post-period reduction in sales either in the short or long-term, nor is there a reduction of sales for competing brands, nor is there a reduction of sales for promoting item in competing retailers. It is a complete category expansion effect.

\subsubsection{Rational Choice Theory (RCT) (Becker, 1992)}

Rational Choice Theory, also known as Choice Theory or Rational Action Theory, is a framework for understanding and often formally modeling social and economic behavior. The basic premise of Rational Choice Theory is that aggregate social behavior results from the behavior of individual actors, each of whom is making their individual decisions. The theory also focuses on the determinants of the individual choices (methodological individualism). Rational Choice Theory then assumes that an individual has preferences among the available choice alternatives that allow them to state which option they prefer. These preferences are assumed to be complete (the person can always say which of two alternatives they consider preferable or that neither is preferred to the other) and transitive (if option $A$ is preferred over option $B$ and option $B$ is preferred over option $C$, then $A$ is preferred over $\mathrm{C}$ ). The rational agent is assumed to take account of available information, probabilities of events, and potential costs and benefits in determining preferences, and to act consistently in choosing the self-determined best choice of action. Rationality is widely used as an assumption of the behavior of individuals in microeconomic models and analyses. It is also used in political science; sociology, and philosophy. A particular version of rationality is instrumental rationality, which involves seeking the most cost-effective means to achieve a specific goal without reflecting on the worthiness of that goal.

\section{Application of the theory to this study}

The theory of Retailer Price Promotions (TRPP) is applying to this study from the point of 
view of the importance of sales promotion to every member in channel of distribution. That is the manufacturer, wholesaler, the retailer, and consumers. All the channel members will benefit from promotional activities ranging from increase in sales volume, market growth, market share and other marketing performances. The theory of Retailer Price Promotions guard the independent variable of this study. Rational Choice Theory is useful to this study from the perspective of dependent variable. This is due to the social and economic factors affecting consumer's choice or decision making toward goods and services.

\subsection{CONCEPTUAL FRAMEWORK}

\subsubsection{Concept of Strategic management}

Strategic management connotes prudent management of a firm's resources to achieve its goals and objectives. It encompasses setting objectives, vision, analyzing the competitive environment, the internal and external environment, formulating, implementing, and analyzing/evaluating the effectiveness of the strategies implemented. "It is the continuous planning, monitoring, analysis and assessment of all that is necessary for a firm to meet its goals and objectives" (Bettis \& Hitt, 1995).

Hitt, et. al., (2017:30) opined that

"flowing from the firm's strategic intent, the strategic mission specifies, in writing, the products the firm intend to produce and the market it will serve when leveraging those resources, capabilities and competencies. The firm's strategic input provide the foundation for strategic action to formulate and implement strategies. Both formulating and implementing strategies are critical to achieving strategic competitiveness and earning above average returns".

\subsubsection{Free sample products on consumers}

Heilman, Lakishyk, and Radas, (2011) presented a "model of free sample effects and evidence from two field experiments on free samples. The model incorporates three potential effects of free samples on sales: (1) an acceleration effect, whereby consumers begin repeat purchasing of the sampled brand earlier than they otherwise would; (2) a cannibalization effect, which reduces the number of paid trial purchases of the brand; and (3) an expansion effect, which induces purchasing by consumers who would not consider buying the brand without a free sample. The empirical findings suggest that, unlike other consumer promotions such as coupons, free samples can produce measurable long-term effects on sales that can be observed as much as 12 months after the promotion. The data also show that the effectiveness of free sample promotions can vary widely, even between brands in the same product category. Application of the model to the data from the two experiments reveals that the magnitude of acceleration, cannibalization, and expansion effects varies substantially across the two free sample promotions. These and other findings suggest that the model can be a useful tool for obtaining insights into the nature of free sample promotions".

According to Heilman, Lakishyk, \& Radas, (2011) "Free sampling is very effective in inducing trial, especially among lower educated consumers. For consumers who are planning to buy the product in the promoted category, free sampling can encourage switching from the planned to the promoted brand. For consumers who do not have such previous plans, free sampling can "draw" them into the category and encourage category purchase. Samplers' interactions with the person distributing the sample or with other samplers at the scene also seem to boost post $\square$ sample purchase incidence". McGuiness, Gendall and Mathew (2015) asserted that "although several claims have been made about the effectiveness of product sampling as a sales promotion technique, there is relatively little published research in support of these claims". Thus, McGuiness, et. al. (2015) in their study of:

"433 New Zealand household grocery shoppers examined the sampling of three newly-launched brands of toothpaste, shampoo, and dishwashing liquid. The rates of sample trial measured were considerably higher than those commonly reported in the literature, but purchase and conversion rates were somewhat lower. There was little evidence that product sampling had any influence on conversion to the sampled brands, except when recipients actually used the samples or subsequently 
purchased the sampled brands as a result of trial. Overall, the samples were not accurately distributed to the brands' most likely prospects, although selective distribution was found to be a worthwhile objective because members of each target market tended to respond well to sampling".

Bawa and Shoemaker (2004), presented, "a model of free sample effects and evidence from two field experiments on free samples. The model incorporates three potential effects of free samples on sales: (1) an acceleration effect, whereby consumers begin repeat purchasing of the sampled brand earlier than they otherwise would; (2) a cannibalization effect, which reduces the number of paid trial purchases of the brand; and (3) an expansion effect, which induces purchasing by consumers who would not consider buying the brand without a free sample. The empirical findings suggest that, unlike other consumer promotions such as coupons, free samples can produce measurable longterm effects on sales that can be observed as much as 12 months after the promotion. The data also show that the effectiveness of free sample promotions can vary widely, even between brands in the same product category. Application of the model to the data from the two experiments reveals that the magnitude of acceleration, cannibalization, and expansion effects varies substantially across the two free sample promotions. These and other findings suggest that the model can be a useful tool for obtaining insights into the nature of free sample promotions."

\subsubsection{Empirical review}

A study on consumer reflection on "buy one get one free" (BOGO) promotion scheme in Malaysia by Jayaraman, Iranmanesh, Kaur, and
Haron (2013), "the study included 111 respondents in Malaysia, who have experienced in purchasing products under BOGO scheme. The relationship between the purchase satisfaction of the respondents and their repurchase intention on BOGO scheme was investigated in the study. Out of 111 respondents, 47 (42.3percent) were highly satisfied on making purchase under BOGO scheme and 52 (46.8percent) have repurchase intentions. The results obtained from the study ascertains that consumers in Malaysia gave more importance to the attributes like value added products and quality and therefore the businessmen engaged in BOGO scheme may focus on these attributes to boost their sales. Based on the purchasing experience of the respondents, 59.5percent favor attractive packaging as the most significant factor for repurchase intentions on BOGO promotion scheme. Further, the study signifies that BOGO scheme is genuine in promoting sales and the businessmen involved in this scheme are highly ethical."

Imaya, and Padhmanaban (2015) conducted an empirical study on sales promotional strategies for wooden furniture in Tamil Nadu State in India, in 2013. The objectives of the study were to examine the effectiveness of various sales promotional measures adopted by wooden furniture manufacturers and dealers in the study area. Primary and secondary data were sourced from wholesalers, retailers and customers available in the selected districts of Tamil Nadu State, and relevant web enabled services, journals, magazines, and newspapers respectively. The study utilised judgmental sampling design to fixing the proper sampling frame. Data estimation was done using simple average, standard deviation, F-test, T-test, ANOVA statistics. The study established a significant relationship between sales promotions strategies and sales volume, in such that industries are taking more steps to promote their sales volume. The study however concluded that the unorganized wooden furniture sector was not able to give sufficient sales promotional strategies due to lack of proper segments.

Familmaleki, Aghighi and Hamidi (2015) carried out a study on analyzing the influence of sales promotion on customer purchasing behavior. The study's objective was to investigate the effects of sales promotion on buyer decision making process. Exploratory research design 
was adopted in the study and the study concluded that consumers buying behavior and sales promotion can be motivated through various kinds of elements, including promotion techniques such as free samples, price discounts, social surroundings and physical surrounding.

\subsection{RESEARCH METHODOLOGY}

\subsection{Research design}

Descriptive research design was adopted in this study. This design was preferred over the others because it is used to find the meaning and obtain an understanding of the present conditions as well as determining the frequency with which something occurs or the relationship between two variables. The results obtained from the design can be analyzed statistically.

\subsection{Study area}

The study area of research was Calabar Metropolis which comprises Calabar South and Calabar Municipality local government areas of Cross River State. It is the capital of the state, and in the southern senatorial district. It is bounded by the North by Akamkpa, East by Odukpani, West by Akpabuyo and South by Atlantic Ocean. It is located at latitude and longitude at $457 \mathrm{~N}$ and $819 \mathrm{E}$ respectively. It has an area of $406 \mathrm{~km}$ and a population of 562 at 2006 population census (N.P.C.;2006). Calabar Metropolis has a number of retail outlets at different sizes and capacities.

\subsection{Population of the study}

The population of this study consists all buyers or products consumers from any retail outlets that offer sales promotion in Calabar Metropolis. Therefore, the total population was unknown.

\subsection{Sample size determination}

The researcher adopted Topman formular to determine the sample size of this study from unknown population of buyers. There was no fund and as such the Pilot survey carried out in different retail outlets was used for the analysis of data. The results were analyzed using
Cronbach's Alpha coefficient to determine the values of positive and negative values of 80 and 20 respectively. Therefore, the sample size for this study was 120 respondents.

\section{Topman formula}

$$
\begin{aligned}
& n \quad=\frac{Z^{2} \bar{P}(1-\bar{P})}{e^{2}} \\
& \text { where } \\
& n^{\prime}=\quad \text { Sample size } ? \\
& Z^{\prime}=\quad Z-\text { Score } 1.96 \\
& P=\quad \text { Positive responses } 0.8 \\
& 1-P=\text { negative responses } 0.2 \\
& \mathrm{e}=\quad \text { tolerable error } 0.5 \\
& n=\frac{(1.96)^{2} \times 0.8 \times 0.2}{(0.5)^{2}} \\
& n=125
\end{aligned}
$$

\subsection{Sampling technique}

Stratified random and judgemental sampling designs were used to select sample elements of 120 respondents been buyers in this study.

\subsection{Source of data collection}

The main source of data collection was primary source.

\subsection{Instrument for data collection}

The questionnaire was used to collect primary data from respondents

\subsection{Validity and reliability of the instrument \\ Content validity of the instrument was} ensure by face validity test. While the reliability of the instrument was estimated by the Cronbach's Alpha coefficient. The coefficient value were 85 percent and above which made the instrument reliable for this study.

\subsection{Data treatment technique}

The data treatment technique were one way ANOVA and multiple regression with the aid of SPSS version 21. 
Table 4.1: Descriptive statistics of the variables

\begin{tabular}{lccc}
\hline & $\mathrm{N}$ & Mean & $\begin{array}{l}\text { Std. } \\
\text { Deviation }\end{array}$ \\
\hline $\begin{array}{l}\text { Consumers } \\
\text { motivation }\end{array}$ & 120 & 16.82 & 3.01 \\
$\begin{array}{l}\text { Consumer } \\
\text { participation }\end{array}$ & 120 & 18.15 & 3.44 \\
\hline
\end{tabular}

Table 4.1 presents the mean and standard deviation of the independent and dependent variables in the study. It reveals that the mean score of consumers participation in sales promotions campaign was 16.82, with standard deviation of 3.01 ; while mean for consumers participation was 18.15 with standard deviation of 3,44 . This implied that respondents agreed above average to the various items measuring sales promotion techniques campaign.

\subsection{Test of hypotheses}

Table 4.2: One way analysis of variance of sales promotions techniques and consumers motivation to participate

\begin{tabular}{|c|c|c|c|c|}
\hline Sales promotions techniques & $\mathrm{N}$ & M & & \\
\hline $\begin{array}{l}\text { Low Technique } \\
\text { Moderate technique }\end{array}$ & $\begin{array}{l}20 \\
35\end{array}$ & $\begin{array}{l}15.42 \\
16.14\end{array}$ & & $\begin{array}{l}88 \\
96\end{array}$ \\
\hline High technique & 65 & 2.19 & & 19 \\
\hline Source of variance & SS $\quad d f$ & Ms & F-ratio & sig \\
\hline Between groups & 64.8712 & 32.44 & & \\
\hline Within groups & 6769.309 & 1175.52 & 5.879 & .003 \\
\hline Total & 6834.180 & 119 & & \\
\hline
\end{tabular}

Significant at $P>0.05$, critical $F 3.196=2.65$

Source: Field work, 2018 
The one way analysis of variance was conducted to investigate sales promotions techniques on customers' motivation to participate. The result in table 4.2 showed a significant effect of sales promotions techniques to motivate customers participation $\mathrm{F}(2,187) 5.879, \mathrm{P}<.05$.
Therefore the null hypothesis which states that sales promotions techniques does not significantly motivate customers' participation is rejected and alternate hypothesis is retained. Given that the result is significant Sidak post hoc test was done to fine where the differences lies and the result is presented in table 4.3.

TABLE 4.3: Sidak post hoc test for differences of mean

\begin{tabular}{|c|c|c|c|c|}
\hline Sales-promo & Sales-pro & Mean difference & Std. Error & Sig. \\
\hline Low & Moderate & -72103 & .24277 & .009 \\
\hline \multirow{3}{*}{ Moderate } & High & -22906 & .21293 & .630 \\
\hline & Low & .72103 & .24277 & .009 \\
\hline & High & .49196 & .16468 & .009 \\
\hline High & Low & .22906 & .21293 & .630 \\
\hline moderate & High & -49196 & 16468 & .009 \\
\hline
\end{tabular}

The mean difference is significant at 0.05 level

Source: Field work, 2018

The result in table 4.3 reveals that there are three groups of respondents, the mean value for respondents in the moderate group is significantly different from those in low group (mean difference $=0.72, \quad P<.05$ ), also respondents in the moderate group significantly differ from those in the high group (mean difference $\quad=\quad 0.491, P<.05)$.

Table 4.4: Model summary

\begin{tabular}{lllll} 
Model & $\mathrm{R}$ & $\mathrm{R}$ Square & Adjusted R-Square & Std. Error of the Estimate \\
\hline 1 & $.685^{\mathrm{a}}$ & .470 & .461 & 3.52801 \\
\hline
\end{tabular}


Table 4.5: ANOVA $^{a}$

\begin{tabular}{lllllll}
\hline & & Sum & of & Mean & & \\
Model & & Squares & Df & Square & F & Sig. \\
1 & Regression & 3868.977 & 3 & 644.830 & 51.807 & $.000^{\mathrm{b}}$ \\
& Residual & 4368.855 & 115 & 12.447 & & \\
& Total & 8237.832 & 118 & & & \\
\hline
\end{tabular}

a. Dependent Variable: Consumer participation

b. Predictors: (Constant), Free Sample, , discounted pricing, coupon.

Table 4.6: Coefficients ${ }^{\mathrm{a}}$

\begin{tabular}{|c|c|c|c|c|c|}
\hline \multirow{3}{*}{$\begin{array}{l}\text { Model } \\
1 \text { (Constant) }\end{array}$} & \multicolumn{2}{|c|}{$\begin{array}{l}\text { Unstandardized } \\
\text { Coefficients }\end{array}$} & \multicolumn{3}{|c|}{$\begin{array}{l}\text { Standardized } \\
\text { Coefficients }\end{array}$} \\
\hline & B & Std. Error & Beta & $\mathrm{T}$ & Sig. \\
\hline & 1.518 & 1.031 & & 1.473 & .142 \\
\hline Free sample & .196 & .053 & .181 & 3.711 & .000 \\
\hline Discounted pricing & .051 & .047 & .051 & 1.085 & .000 \\
\hline Coupon & .080 & .035 & .095 & 2,268 & .067 \\
\hline
\end{tabular}

a. Dependent Variable: Consumer participation

\subsection{SUMMARY OF RESULTS}

\section{Decision rule}

If the $p$ value is greater than the significance level of 0.05 , accept the null hypothesis $(\mathrm{Ho})$ and reject the alternative $(\mathrm{Hi})$. But if the $p$ value is less than the significance level of 0.05 , reject the null hypothesis $(\mathrm{Ho})$ and accept the alternative $(\mathrm{Hi})$.

Tables 4, 5 and 6 report the regression analysis carried out to test the hypotheses of this study. The results show that there is a significant (joint) effect of free sample, discounted pricing, and coupon on consumer participation $(\mathrm{F}=$ $51.807, \mathrm{P}<0.05)$. Tables 4 and 5 further report a significant $F$ statistic, indicating the model's prediction strength $\left(R^{2}=47, p<0.05\right)$. The $R^{2}$ of 47 percent implies that for every unit change in consumer participation, 47 percent of such variation is jointly attributed to or explained by free sample, discounted pricing and coupon scheme.

Hypothesis two:

$\mathrm{Ho}_{1}$ : There is no significant effect of free sample on products consumers of selected retail outlets in Calabar metropolis.

Table 4 shows that, on individual basis, there is a significant relationship between free sample and consumers participation $\left(b_{1}=0.196\right.$, $p<0.05)$. Beta value for free shipping which is .181 has made significant contribution in the model. Therefore null Hypothesis One was rejected while alternative accepted.

\subsection{DISCUSSION OF RESULTS} retail outlets.
Free sample and consumers of selected 
It is revealed in the analysis of data and information gathered in this work that free sample has a significant effect on consumer performance is the one of the highest contributors to the model. This indicates that consumer look out for free sample of goods before purchase is made. This result corroborates with that of Koukova et al. (2012); Rosen and Howard (2000) which opined that Product sample is an essential component of retailing. This would out turn the belief that in offline retailing, the buyers often reject free sample of products. The spatial remoteness (between firms and customers) of online retailing necessitates the firms taking over the costs of order delivery (Koukova et al. 2012; Rosen \& Howard 2000). The essential role of sample in offline retailing further highlights them as an important component of competitive advantage among retailers, especially given that consumers are sensitive to both the product price and the shipping cost (Dinleroz \& Li 2006; Smith \& Brynjolfsson (2001). Therefore, decisions related to shipping charges are important for offline retailers.

This result establishes that many small businesses use giving away free gifts as a marketing strategy to attract attention; find new customers and build brand loyalty. This result corroborates Wagner, (2018) assertion that the "freebies don't always work the way retailers want, putting a strain on a tight budget that could have been used elsewhere to market product or service. Knowing the pros and cons of giving away free gifts as a way to increase business is key to choosing an item that grabs attention and causes the recipient to come back and buy. Freebies attract two types of crowds -- those that might buy your product and people who just want the freebie and who never intend to buy from you. This is often the case at trade shows, where some people just want to fill their "goodie" bag and have no intention of buying anything. The best way to eliminate the freeloaders is to qualify the person as a potential prospect by asking questions and finding out their level of interest in your product or services. Then, even if they don't buy immediately, at least you know there's interest. On the other hand, providing a small freebie to everyone, such as a free makeup sample if you own a beauty salon, helps those who are interested in what you sell to become repeat customers if they find the product worth buying".

\section{CONCLUSION}

The main crust of this research study was to investigate the effect of sales promotion techniques on products consumers of selected retail outlets in Calabar Metropolis. Specifically, the use of this industry is very interesting and helpful in order to verify the significance of sales promotions to consumers, as retailing is one of the major channels of distribution that is very close to consumers and the other members of the distribution channel depend on it for distribution of convenient goods and services to the consumers.

The following conclusion was made after a careful study of the research findings and the literature reviewed. The ultimate objective of every business is to increase the sale of goods that it deals in. Several methods can be adopted for the achievement of this goal; some direct while others indirect. Sales promotion is one of them.

Sales promotion has become a valuable tool for the marketers and importance of it has been increasing rapidly over the years. On the basis of the findings of this study, it can be concluded that sales promotion dimensions have significant influence on consumers' performance. Buyers would patronize a retail outlet that could offer one or two of these sales promotion tactics. In the case of free sample, buyers would prefer to patronize a retail outlet that will offer free product samples. It is pertinent to note that not all retail outlets are competent enough to carry out sales promotion. But those who can adopt the scheme have competitive edge over others. This is the technique used by dealers of fast moving consumers' goods like convenient retail outlet, and so on.

The consumers are more prone to sales promotion and exhibit switching behavior between two or more brands of product to take the advantage of the promotional discounts. As the results also indicate that, the monetary savings have high impact on the consumer performance as compare to the other factor that is non-monetary factor.

\section{RECOMMENDATIONS}

The following recommendations were made for this study:

1. Retailers should endeavor to engage in sales promotions strategies vigorously as this would promote sales volume in order 
to obviate expiry date of some products on the shelf.

2. Giving free products to consumers and charging a token should be discouraged, as this practice disenchant many consumers and impairs brand loyalty as many consumer are not ready to come back to patronize such product.

\section{REFERENCES}

Barney, J. B., 1995. Looking inside for competitive advantage. Academy of Management Executive. 9(4), 49-61. DOI.Org/stable/4165288.

Bawa, K. and Shoemaker, R., 2004. The effects of free sample promotion on incremental brand sales. Marketing Science 23, (3), 345-363.DOI.org/10.1287/mksc. 1030.00 52.

Bettis, R. A. and Hitt, M. A., 1995. The New Competitive Landscape. Strategic Management Journal, 16(1995),7-19.

David, F. R. and David, F. R., 2015. Strategic management: Concepts and cases. $\left(15^{\text {th }}\right.$ Edition), New Jersey: Pearson Education Inc.

Dinleroz, M. and Li, A. G., 2006. The determinants of consumers' online shopping cart abandonment. Journal of the Academy of Marketing Science, 38 (2), 240-250.

Effiong, C. and Ekpenyong, O. E., 2010. The strategic management of the advertising messages in Nigeria. Proceedings of the 2nd annual international conference on Economic, Business and Entrepreneurship in Africa, Organised in Collaboration with the Academy of Business And Public Policy, hosted by the Centre for Entrepreneurial Development, University of Uyo, Nigeria., March 9-11, 2010. pp 26-37.

Effiong, C., Usoro, A. A. and Ekpenyong, O. E., 2017. The impact of labour turnover on small and medium scale enterprises (SMEs) performance in Cross River State, Nigeria. IOSR Journal of Business and Management 19(10), 40-57.
Familmaleki1, M., Aghighi, A. and Hamidi, K., 2015. Analyzing the Influence of Sales Promotion on Customer Purchasing Behavior. International Journal of Economics \& Management Sciences. 4(4),1-6

Hashim, M. K., 2005. Strategic Management. Singapore: Thomson Learning, ISBN 9812545336, 9789812545336

Heilman, C. M., Lakishyk, K. and Radas, S., 2011. An empirical investigation in-store sampling promotions. British Food Journal, 113: 1252-1266.

Hitt, M. A., Hoskisson, R. E., Harrison, J. S. and Summers, T. P., 1994. Human Capital and Strategic Competitiveness in the 1990s. The Journal of Management Development, 13(1), 35-46.

Hitt, M. A., Ireland, R. D, and Hoskisson, R. E., 2017. Strategic management: Competitiveness and globalization $\left(12^{\text {th }} \mathrm{Ed}\right.$.) Boston, MA: Cengage Learning.

Imaya, M. and Padhmanaban, K., 2015. Sales promotional strategies for wooden furniture. Asia Pacific Journal of Research. 1(21), 77-86.

Jayaraman, K., Iranmanesh, M., Kaur, M. D. and Haron, H., 2013. Consumer reflections on "Buy One Get One Free" (BOGO) promotion scheme - An empirical study in Malaysia. Research Journal of Applied Sciences, Engineering and Technology 5(9), 27402747. DOI:10.19026/ rjaset.5.4800.

Kotler, P. T., 2002. Marketing management millennium edition. $\left(10^{\text {th }}\right.$ ed.) New Jersey: Pearson Education Company.

Kotler, P. T. and Armstrong, G., 2013. Principle of Marketing. (15th Edition), New Jersey: Prentice Hall.

Koukova, N. T., Srivastava, J. and Steul-Fischer, M., 2012. The effect of shipping fee structure on consumers' online evaluation and choice. Journal of the Academy of Marketing Science 40(6), 759-770.

McGuiness, D., Gendall, P. and Mathew, S., 2015. The Effect of Product Sampling on Product 
Trial, Purchase and Conversion. International Journal of Advertisimg, 11 (1), 83-92.

DOI.Org/10.1080/02650487.1992.11104 479.

Omalaja, M. A. and Eroula, O, A., 2011. Strategic management theory: concepts, analysis and critiques in relation to corporate competitive advantage from the resource-based philosophy. Economic Analysis 44(1-2) 59-77.

Rosen, K. T. and Howard, A. L., 2000. E-retail: gold rush or fool's gold. California Management Review, 42(3), 72-100.

Smith, M. D. and Brynjolfsson, E., 2001. Consumer decision-making at an internet shopbot: Brand still matters. Journal of industrial economics. 49(4), 541-558. DO1.Org/10.1111/1467-6451.00162
Wagner, N., 2018, June $30^{\text {th }}$. The pro and cons of free gift campaigns. Retrieved from http://smallbusiness.chron.com/ proscons-gift-campaigns-70314.html,

Xia, L. and Monroe, K. B., 2004. Price partitioning on the internet. Journal of Interactive Marketing, 18(4), 63-73. 